al-Ihkam: Jurnal Hukum dan Pranata Sosial, 14 (1), 2019: 50-71

ISSN: 1907-591X, E-ISSN: 2442-3084

DOI: http://doi.org/10.19105/al-ihkam.v14i1.2159

\title{
The Study of Maqâshid Syarî‘ah Toward Maduresse Traditional Inheritance by Using System Approach
}

\author{
Mohammad Hipni \\ Trunojoyo University of Madura, Jl. Raya Telang Kamal Bangkalan \\ Email:busyro.pro18@gmail.com
}

Article history: Received: 20 Februari 2019, Accepted: 27 Juni 2019, Published: 11 Juli 2019

\begin{abstract}
:
In traditional societies such as Maduresse who carry out religious teaching strongly, women in certain contexts are generally positioned in the lower position than men. However, in the cultural context of Maduresse inheritance, women are on the equal footing with men. Even, parents give more priority on the legacy to their daughters. The purpose of this study is to understand the phenomenon of the women position in traditional Maduresse legacy by using maqâshid sharia particularly the system approach. The use of system approach aims to explain parts that influence the position of women in Maduresse traditional inheritance system and determine the legislation ratio on the legal phenomenon. This research discovers that women in Madurese society are considered not only as passive family members, but also as a symbol of honor and sustainability in Madurese family. These arguments make Maduresse's understanding on the inheritance verses more comprehensive. Therefore, women are positioned equal with men for the legacy distribution in Madura traditional inheritance.
\end{abstract}

\section{Keywords:}

Islamic Jurisprudence; Cultural Legacy Distribution; System;

Madurese

Author correspondence email: busyro.pro18@gmail.com Available online at: http:/ / ejournal.iainmadura.ac.id/index.php/alihkam/ Copyright (c) 2019 by al-ihkam. All Right Reserved 


\begin{abstract}
Abstrak:
Pada masyarakat tradisional seperti Madura dengan karakter keras memegang teguh agama, wanita pada konteks tertentu diletakkan dalam posisi yang lebih rendah dari pada laki-laki. Namun, dalam konteks kewarisan adat Madura, wanita diposisikan setara dengan kaum laki-laki. Bahkan, orang tua memberikan prioritas lebih atas bagian waris anak perempuannya. Penelitian ini bertujuan memahami fenomena kedudukan wanita dalam waris adat Madura dengan menggunakan maqãshid syarîlah khususnya pendekan sistem. Analisis sistem ini diharapkan mampu menjelaskan bagianbagian yang memengaruhi kedudukan wanita dalam sistem waris adat Madura dan mengetahui ratio legis dari fenomena hukum tersebut. Penelitian ini menghasilkan temuan bahwa wanita dalam masyarakat Madura dianggap tidak hanya sebagai anggota keluarga pasif, namun sebagai simbol kehormatan dan simbol keberlangsungan keluarga masyarakat Madura. Pandangan yang demikian membuat pemahaman terhadap ayat waris lebih komprehensif. Oleh karena itu, wanita diposisikan setara dengan laki-laki dalam pembagian waris adat yang dipraktikkan dalam adat masyarakat Madura
\end{abstract}

Kata Kunci:

Hukum Islam; Waris Adat; Sistem; Madura

\title{
Introduction
}

Legacy is one of Islamic main lessons that every Moslem should obey. Islam divides the legacy comparison for men and women in 2:11 quantification. This rule is qath' $\hat{\imath}$ (definite) ${ }^{2}$ and supposed to be the main guide for all Moslems, ${ }^{3}$ including Maduresse people whose majority is Islam believers. Any break of the legacy rule is considered as the infraction of Allah's command ${ }^{4}$ and threatened with the hell's torture. ${ }^{5}$

\footnotetext{
${ }^{1}$ Q.S al-Nisã' (4): 11

2 Rachmat Syafe'i, Ilmu Ushul Fiqih, (Bandung: Pustaka Setia, 2015), 56

3Wahbah Zuhailĩ, al-Tafsĩr al-Munĩr: Fi al-'Aqîdah wa al-Syarî'ah wa al-Manhaj, Vol. II,(Damaskus: Dãr Fikr, 2003), 608

4 The sentence used in Al-Quran is washiyyatan min al-Allah, Allah's testament. The meaning of the testament is mentioned at the next verse "those are the limitation of Allah", so al-Sayyuti considers it as Allah's order. Al-Sayuthĩ, al-Dzurr al-Manthûr al-
} 
On the basis of it, Maduresse people who are famous of their great religiosity ideally practice the division of legacy in accordance to Islamic rules. However, Maduresse people do not always literally use the Islamic rules mentioned in al-Qur'an as the main source in the practice of "legacy division". Sometimes, a Maduresse woman gets more preferential treatment than a man. A daughter may get a house and a field of land for her legacy while her brother only gets a land. In the doctrinal level, a Moslem must obey all of religious teachings perfectly (kaffah), whether they like it or no. What makes this research important and interesting is because it portrays a phenomenon of Maduresse people who use inappropriate legacy rules on the Islamic legacy point of view. This study will engage religious, social, and cultural aspects that are systemically built in Maduresse life particularly relating to the legacy division. The Maduresse traditional legacy system was absolutely built based on the strong ratio of legislators that it later becomes a fact of Islamic law with a special characteristic. This research is trying to discuss the "istinbath (conclusion making)" of Islamic law model among Madurese people by using maqûshid syarî'ah particularly the system approach.

The previous researches about maqâshid usually revolve in episteme level and still do not engage axiology level. To mention some, there found researches by Ali Mutakin, ${ }^{6}$ Maulidi, ${ }^{7}$ and Sadari ${ }^{8}$ that concerned at most with maqâshid as the istinbath law method. Meanwhile, the study about application of ijtihâd maqâshidi products in people's life is still rare to find. ${ }^{9}$ This research gives the application of ijtihâd maqâshidi in a partial case in a certain people's life. Using this

Tafsĩr bi al-Ma'tsûr, Juz IV, (Kairo: Markaz lil Buhũs wa al-Dirāsah al-'Arabiyyah wa al-Islamiyah, 2003), 270

${ }^{5}$ Q.S al -Nisã' (4): 14

6 Ali Mutakin, “Teori Maqashid al-Syariah dan Hubungannya dengan Metode Istimbath Hukum" in Kanun Jurnal Ilmu Hukum, Bol 19 No. 3, August, 2017.

7 Maulidi, "Paradigma Progresif dan Maqashid Syariah: Manhaj Baru Menemukan Hukum Responsif", in Asy-Syir'ah: Jurnal Ilmu Syariah dan Hukum, Vol .49 no. 2, December 2015

8 Sadari, "Qur'anic Studies: Ber-ushul Fiqh dengan Maqashid Syariah sebagai Metode dalam Prespektif Adian Wahyudi, in Shahih, Vol 3 No. 1 January, 2018.

9 The study of ijtihad maqashidi has ever been done by Abdul Mukti Thabrani, "Maqashid Revitalization in Global Era: Istidlal Study from Text to Context" in alIhkam, Vol. 13 No.2 Desember 2018. 
approach, it is wished that this research can comprehend Maduresse people local wisdom in doing "ijtihâd" and understanding the traditional legacy division.

\section{The System Features as Islamic Law Phenomenon Understanding Method}

According to Singer, as it is cited by Danandjaja, understanding the essence of reality in the society begins with the willingness to see human as an individual who lives in a certain culture as the place where they interact each other. ${ }^{10}$

From the basic concept and the framework above, phenomenon of Maduresse traditional legacy looks as the pull and push reality between Maduresse people as individuals and various backgrounds they come from in a side and its existence as the social reality or common rules of Madurese people in dividing the property to their generation in another side. To understanding the complicated phenomenon, the writer uses qualitative research through maqâshid sharia as the research paradigm and the system approach as the main analysis method.

Maqashid sharia with its system approach is basically used as istinbath method to predict and answer many kinds of Islamic law problems so that it would be still compatible to the current development. However, its use in this research is as a method to understand a certain fact of Islamic law among certain people. Therefore, here, the Maduresse traditional legacy phenomenon is used as the object of the study which would later be analyzed using the approach system of maqâshid syar'iyyah framework. Its use is wished to get comprehensive understanding on Maduresse traditional legacy.

Theoretically, maqâshid syarî'ah is a value that shari'a tries to maintain through some rules extracted from religious texts to ensure the human being's interest remains well kept.11 In other word, maqâshid syarî'ah is the essence or spirit of Islamic law regulated to human as the God's servants. If it were not because of the values in

\footnotetext{
10 James Danandjaja, Antropologi Psikologi: Teori, Metode dan Sejarah Perkembangannya, (Jakarta: Rajawali, 1988), 89

11 Saad Ahmad al-Yũbĩ, Maqãshĩd al-Syãri'ah al-Islamiyah wa Alãqatihã bi al-Adillah alSyar'iyyah, (Saudi Arabiya: Dãr Hijrah li an-Nasr wa al-Tawzĩ', 1993), 38
} 
maqâshid, there would have not been found any law that Allah regulates. Therefore, maqâshid syarî'ah is considered as illat (main cause) on any tasyrî' (law making) that Allah gives to his servants. ${ }^{12}$

Meanwhile, according to Indonesian Language Dictionary, system is a set of elements that are strictly connected to each other in forming the totality. ${ }^{13}$ One of which is the totality of social reality. In this case, the system refers to Maduresse traditional legacy division that contains spirit of women's empowerment inside its division. The use of system approach in this research is due to its characteristic, which is to know and understand related elements which form the Maduresse traditional legacy division system model.

Furthermore, the system approach used in this study is the approach of Jasser Auda, a contemporary Islamic thinker. Auda is a maqâshidi (expert of maqâshid syarîah) who tried to bridge the gap between Islamic texts and Moslem's changing problems. In many previous studies, he used maqâshid syar'iyah as the main basic ${ }^{14}$ and system approach as the basic method. The basic concept of system approach and analysis uses wider approaches and makes it possible on the interrelatedness among some features as follow; Seeing the whole research object (wholeness), being open to the improvements (openness), the interrelation of some values (interrelated hierarchy), engaging some dimensions (multidimensionality), and giving priority on the main purpose (purposefulness). ${ }^{15}$

The system is also called as cognitive science considering that every concept of science, whatever it is, always involves the mind intervention or human cognition. It cannot be imagined that a perfect

\footnotetext{
12 In the realm of learning tauhid, particularly the 'illat on action ( fi'l) of Allah, there found a long debate since the beginning of ilmu kalam discussion. The long debate was among Muktazilah, Asy'ariyyah, Matũridiyyah, Dhãhiriyyah etc. However, the debate about illat was not continued to figh science realm, where there found a deal of illat law. See, 'Ãdil Syuwaĩh, Ta'lĩl al-Ahkãm fi al-Syari'ah al-Islamiyyah, (Thantah: Dãr Basyir li al-Tsaqafah wa al-`Ulũm, 2002).

13 KBBI

14 Jasser Auda is a scholar who learns about maqasid syariah. His published works on this theme could be said almost complete ranging from the early maqasid, maqasid for beginner (2008) until the development of his work Maqãsid al-Syaríah as Philosophy of Islamic Law: A System Approach (2007)

15 Jasser Auda, Maqasid al-Shari"ah as Philosophy of Islamic Law: A System Approach, (London: The International Institute of Islamic Thought, 2007), 45-55.
} 
concept could stand by itself without the participation of mind. Abstract concepts like classification, categorization, and also cognitive nature from (pure) law, for example, will be used to develop the fundamental concept of Islamic law theories as the research object. In the very first time, this approach was used to construct Islamic science generally, but the writer also uses it in discussing elements of Maduresse traditional legacy that are related each other in building a reality.

The use of this approach system in ijtihad maqâshidi model impacts to the changing view on figh. Figh which before was considered divine revelation and therefore cannot be logically understood turns to be a product of human cognition and is supposed to be in line with prosperity and justice. ${ }^{16}$ Here is the point of view comparison on figh between ushul figh conventional approach model and maqâshid syarî'ah model using system approach.

Figure 1. Conventional

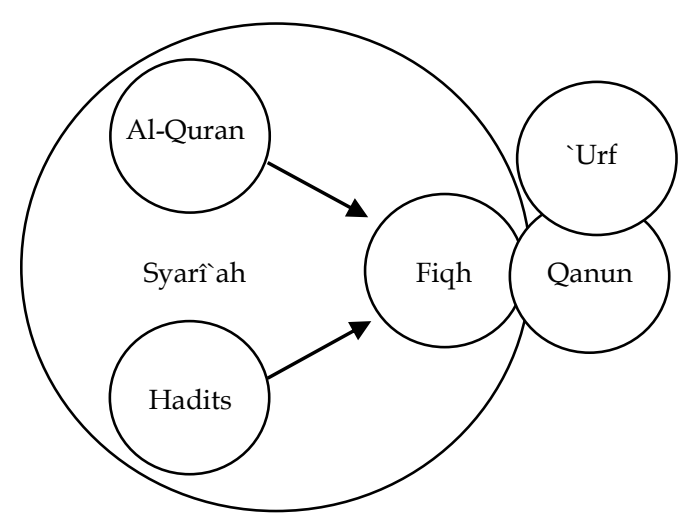

16 Absori, “Transformation of Maqashid al-Syari'ah (An Overview of the Development of Islamic Law in Indonesia), in al-Ihkam, vol 11, No I June, 2016. Also, see the work of Hasan Hanafi which stated the importance of revelation contextualization as the representative of human's "understanding" toward God's words. Hasan Hanafi, al-Ijtihadi al-Kalami, (Lebanon: Dar al-Hadi, 2002), 332. See also Wael B. Hallaq, An Introduction to Islamic Law, (USA: Cambridge University Press, 2009. Meanwhile, Bassam Tibi looks the Islamic law as open texture, Bassam Tibi, Islam and the Cultural Accomodation of Social Change (America: Wastview Press, 1991). 
The picture above shows how the past muftis (fatwa issuers) made the figh closed. Figh was a part of sharia in the same level with The Qur'an and The Hadis. It is unreachable by human's logical thinking and in the untouchable area. Hence, the change of law due to any difficulty or urgency was never easy to do. Any idea or effort to discuss the figh was considered the same as disturbing the purity of the sharia. Meanwhile, the contextual value of human life, or so called urf was only seen as the external factor which does not give any impact on figh. In fact, urf was even seen as the effect of figh application. Different from it, implementation of kanun was considered as the duplication result of figh or in another word, kanun became the interaction of those three. ${ }^{17}$

Jasser Audah offered quite significantly different diagram. On his perspective, figh that was categorized as integral part of sharia needs to be pulled out from untouchable realm to another area in which logical reasoning could take place. Thus, figh must be a part of mujtahid's logical system which is full of interrelated values. The model of system approach is as the illustration below:

Figure 2. System Approach

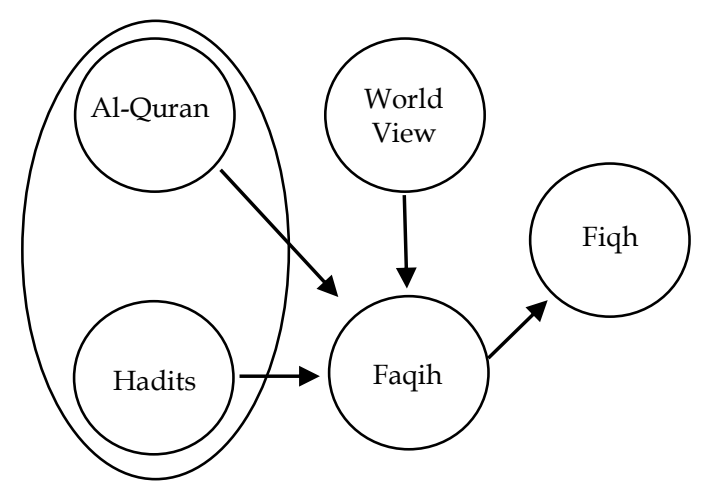

The picture shown above is an effort of mujtahid in pulling out figh from the realm of untouchable revelations to the touchable ones. Fiqh is put as the logical product of a fâqih or figh expert after some

17 Jasser Auda, Maqãshid al-Syarĩah as....., 58. 
enrichment process of influencing potentials. The process uses some features of system as identified before. For example, cognition feature is not only used to pull out figh from the realm of revelation to the realm of science, but also for enriching the prophet's Sunnah. Sunnah is no longer fully considered as khithab or the law imposition, but further divided into three parts: Sunnah as a law that Moslem need to obey; Sunnah as a law with a certain specification, so the execution/performance must be appropriate to the specification, and the last, sunnah is as human's behavior. This perspective on the Prophet's sunnah really affects the ways the process istinbath based on Prophet's sunnah takes place. ${ }^{18}$

In the last picture, it is clear that a faqih with his surrounding elements becomes the central of istinbath. Faqih is supposed to be able to integrate the sharia universal values ${ }^{19}$ (maqâshid syarî'ah) with some noble world views in order to produce a figh product which is compatible to any change and development of nowadays Moslem. In the perspective of system approach, the role of a faqih in istinbath process of Islamic law is to use all features in maqâshid sharia paradigm to create a responsive figh product.

\section{The Woman Existence in Madurese Traditional Legacy Law}

The focused locus of this research is in Bangkalan. This limitation aims to get the valid Maduresse traditional legacy portrait, especially for the women portion and position. To reach that purpose, the data explanation about the elements of Madurese traditional legacy development is explored in balance. Those include data about culture, family and religion system which all of them are considered important in the data compilation.

In this research, respondents come from two different typologies. The first typology consists of those who represent the village and city culture. Meanwhile, the second makes education level as basic for selecting respondents.

Figure 3: Respondents' Data

\begin{tabular}{|l|l|l|}
\hline Respondent & Education & Domicile \\
\hline
\end{tabular}

18 Ibid, 195-196

${ }^{19}$ Fazlur Rahmãn, Islam, (London: Chicago University, 1979) 


\begin{tabular}{|l|l|l|}
\hline H. Baidlowi & $\begin{array}{l}\text { Islamic Boarding } \\
\text { School }\end{array}$ & Kwanyar Subdistrict \\
\hline Dlawi & Senior High School & Socah Town \\
\hline Anita & S1 (Bachelor) & Bangkalan Town \\
\hline Nasruddin & Local Public Figure & Kwanyar Subdistrict \\
\hline Iqbal & S1 (Bachelor) & Bangkalan Town \\
\hline Ansori & $\begin{array}{l}\text { Islamic Boarding } \\
\text { School }\end{array}$ & Kwanyar Subdistrict \\
\hline
\end{tabular}

This research is a qualitative one because it studies the law practiced in a certain society, Madura, as a cultural system. ${ }^{20}$ In the realm of law research, a research on any law applied in a society is categorized as empiric law research. The law research itself could not be separated from social and cultural life where the law lives and develops. Hence, Maduresse traditional legacy research is important to do in order to know the cultural and social portrait and how it is practiced.

\section{The Portrait of Bangkalan's Culture}

According to folklore, the name of Bangkalan was taken from Maduresse language "bangka" and "la'an". Bangka means dead from the very rude Maduresse language. This word is usually spoken to a rude or hated people who died. While $l a^{\prime}$ an means done or finished, so both of the words are combined into one and named for a town, Bangkalan. The history of these two words combination particularly came from folklore about $K e^{\prime}$ Lesap's rebellion that was ended by the murder of Bangkalan's Adipati, Cakraningrat V.21

Bangkalan's and Maduresse people are mostly Moslem. Their point of view never gets apart from religion as the basic value of their life. According to them, religion is not just a basic life view, but also their identity as Maduresse people. ${ }^{22}$ It is an undeniable sociological fact of Madura that mostly, its people are Moslem. This indicates that religion is the important value of Maduresse people. Their loyalty on religion has become their identity. Among others, this is clear from the way local people get dressed, like wearing samper (a long fabric for

\footnotetext{
${ }^{20}$ Nur Syam, Islam Pesisir (Yogyakarta: LkiS, 1995), 2.

21 Abdurahman, Sejarah Madura, Selayang Pandang, (Sumenep: 1971. s.a), 33

22 Latief Wiyata, Mencari Madura, (Jakarta: Bidik-Phronesis Publishing, 2013 ),. 3
} 
Maduresse women's traditional skirt), kebaya, burgo' (women's head cover), sarong (men's skirt) and songko' (men's rime less cap) as the clothing style of Maduresse people which also symbolize the Islamic traditional fashion of local Moslem villagers. ${ }^{23}$

For Maduresse men villager, the wearing of songko' does not only give a unique value, but also symbolize strong willingness to study religious teaching. This is as what has been said by H. Baidlowi, "oreng lok akocca'an jiah bisa arosak ka derejedeh orang jiah. Apapole cak keaeh, oreng se lok toman akocca'an bisa eangghep oreng lok adil sehingge lok bisa deddih bellinah anaknah. "24 (those who do not wear songko' break their dignity by themselves. Moreover, one of the local Islamic leaders (kyai) said that a man who does not wear songko' cannot become the marriage guardian for any bride). The quotation implies an effort to include the local culture to the religious value so it would become a part of must-done religious practice.

Furthermore, the shape of songko' in Madura, especially Bangkalan, shows social degree identity of those who wear it. The white songko' is usually worn by a man to show his identity as a student of Moslem schools whether he had gone for hajj or not yet. When combined with sorban (a kind of turban), it indicates that the wearer is a religious leader. Meanwhile, the black songko' with the sharp corner at the front and back sides with a higher size than the normal is worn by a person with a wide relation or so called blater). This is different from the black songko' with a normal size as it is usually worn by common people.

Besides religion as the basic point of view in facing any realities, the pride or prestige is another basic value of Maduresse people. ${ }^{25}$ This leads to the good behavior of respecting each other as it is clear from the proverb mon etobi' sake,' jek nobik oreng laen, (if being pinched is painful, do not pinch others). This perspective also creates the common norm of the interaction called as adhet tatakrama kasopanan (polite behavior). This norm is the term of understanding and obeying habitual rules of the society which manages relation among

${ }^{23}$ Mien Rifa'i, Manusia Madura, (Jakarta: Pillar Media, 2007), 446

24 The interview's result with H. Baidowi in October 2, 2018.

25 Maulana Surya Kusumah, "Sopan, Hormat, dan Islam Ciri-ciri Orang Madura", inKepercayaan, Magi, dan Tradisi dalam Masyarakat Madura, (Jember : Penerbit Tapal Kuda,2003),. 18 
generation, degree, and gender, whether in the society or private community. ${ }^{26}$ This politeness cultural practice is applied strictly in order to minimize the violation of the norms mainly those categorized as the hard violation because the doers would be regarded as "lok taoh adhet" which means those who do not understand the politeness culture.

The proverb lok taoh adhet refers to a very bad connotation among Maduresse people. They will certainly get offended when referred with the proverb much more than considered materially poor or do not understand religious teaching. This is as what had been said by Iqbal as following; "mon oreng laok taoh ngajih, jiah bisa eajek dek keaeh, tapeh mon oreng lok thaoh adhet, pas bengataonah norok kabbi". (If a person cannot read the holy Qur'an, he or she is still able to learn to a religious leader. But if $\mathrm{s} /$ he does not know about culture, all of his or her ancestors get the bad stereotype as well). ${ }^{27}$ The violation on culture, therefore, causes the ancestors get bad impact right away as they would be considered not teaching their offspring education about culture. For Maduresse people, this is so embarrassing.

The violation makes Maduresse people so embarrassed (malo). This particularly relates to very bad deeds which harass the pride through any disturbance on the wife, family members, and property. The disturbance on women or wife is the biggest reason of Maduresse people to feel offended and get their pride trampled. Women are considered as weak creatures which need protection as well as become the symbol of pride for Maduresse people. It is very clearly shown in Madurese proverb saying "oreng bini' mateh e lencak, reng lakek mateh abedek dere" (a woman is died on the bed, while a man is died covered in blood). Meanwhile, property becomes the last reason after the wife and family members because the stealing of property is not considered as a very big threat for Maduresse people's pride. Maduresse crime of stealing the property is more considered as an embarrassment to the family and neighbor as the one whose properties are stolen would only be mentioned as coward because of inability to maintain his property.

\footnotetext{
26 Ibid, 11.

27 The interview with Iqbal in October 3, 2018.
} 
Another reason of Maduresse people's embarrassment is due the harassment on family members. The bengatoah (ancestor) pride is manifested in a family relationship. Therefore, sometimes, the spirit to maintain the family's pride seems "too strict" and unable to compromise when one of the family members gets a threat. To maintain harmony and keep the spirit of family protection, Maduresse people generally do some efforts through many ways: visiting each other, especially from the younger to the older in some special good days, nyambung bheleh through marrying other family members who either geographically or genealogically far, as known as mapolong tolang, etc. The spirit of protecting each other is also clearly represented in the proverb "rampak naong beringin korong".

After having explanation of Maduresse society life portrait in many aspects ranging from social, cultural, perspective, character and religion system, it comes as urgency to discuss the importance of ratio legis for a law practice in a certain society's entity. Therefore, the next part would explain the law practice of Maduresse traditional legacy.

\section{The Division of Maduresse Traditional Legacy}

The transfer of wealth between generations is called inheritance. In Maduresse people's tradition, if the transfer happens when the giver is alive, it would be named as hibbe (hibah, grant). After the transferring process is done, the heritage is then called as sangkolan. Sangkolan has more meaning than just getting the legacy. More than that, it has a cultural meaning about loyalty toward parents as the legacy (sangkolan) giver.

Sangkolan in Maduresse tradition is likened to the eternal relationship between parents and their kids. As long as sangkolan does still exist, the primordial relationship between parents or ancestors and their children still continues. The eternity of sangkolan is clear from what was mentioned by Dlawi. According to him, sangkolan is the symbol of loyalty to parents and the soul maturity of its recipient. Furthermore, sangkolan is considered as the family's identity that should be kept seriously. The inability to keep it, such as by selling or giving it to other people out of family members would raise the stigma for its doer as tak jeg-jeg or those with no convictions or life 
goal because the effort of keeping it is regarded the same as an effort of obedience to parents.. ${ }^{28}$

In Maduresse culture, the parents as the owners - and giversof the legacy become the central process of traditional legacy. According to Madurese people, parents are considered as pangeran katon (the visible God). Hence, their words are strongly believed as having magical meaning and good impact for the future. A Maduresse proverb clearly describes it by saying "bupak babu guru ratoh cakna kaeh". It means that Maduresse people should respect their parents, teachers, and king or leader. This proverb is still well kept as a cultural value of Madurese people nowadays.

Practically, the parents divide and decide each legacy of the heirs based on several considerations as their prerogative right. Any consideration that parents have is believed as the reflection on how they protect and nurture the kids. One little example is from the Anita's family which lives in Bangkalan town. When her father was alive, he gathered his kids to tell all about his property. According to Anita, the property was initially inheritance of her grandparents from two sides, her father and her mother. Her father's property consists of a field of land from her grandfather after the division among four siblings, including her father, with equal counting.

The field which was the only property belonging to Anita's father is then given to Anita and her brother now, so it is divided into two parts. One is for Anita, and another one is for her brother, Abdullah. However, because of Anita's consideration as a married woman who has got her own house with her husband, Anita sold it to Abdullah, her brother, who bought it with some grams of gold. After the land was fully owned by Abdullah, he built a house and stay there with his family. Meanwhile, Anita's mother's property is also divided into two parts; Anita gets a field of land and her brother, Fauzan, got two parts of rice field as the sangkolan from their mother. ${ }^{29}$

In some cases of legacy, Maduresse parents often consider the daughter as their priority much more than the son. It is shown by the unbalanced legacy division between men and women, where a daughter gets much more legacies than a son. This is particularly clear

\footnotetext{
28 The interview result with Dlawi in October 4, 2018.
}

29 The interview result with Anita in October 3, 2018. 
from the case of Nasruddin's family in deciding those who will stay at home to live with him as a parent.

“Dấ'iyyeh, Hip. Mon orèng towa ka anak jiyâ adek se kemma'a. Lo' sè lakè', lo' sè bini, padâ kabbi monggu reng towa. Mon teppaè apolong rowa cè sennengah. Tapè tempo karè wâa' duwââan, rèng towa kapèkkèran. Bhấ andi' sè èkakana tang ana'. Mangkana engko' ngapolong Kholifah riya. Mon sè lakè' dina marè nyarè kasab dhibi'. Rèng lakè' lakar kapranah akasab. Mon rèng binè', iyâ lakèna mon andi' kasab. Bân polè engko' la towa, dina engkok minta rabet Khalifah. Polana mon rèng binè' biasana pratèn bân alos. Mon apolong anak lakè', masa' engko' minta'a rabet ka manto, ana'en orèng. Iyâ mon bellâs." 30 (It goes on like this, Hip. Parents would consider all of kids the same no matter they are men or women. It feels beyond happy to welcome them together here. As they grow up and get married, I still keep in mind on them, whether they have money to pay the bill or not. Therefore, I stay here with Khalifah, my daughter. I do not do the same for my son as he would go as the breadwinner. Meanwhile for my daughter, it is her husband who would be his breadwinner, if he does so. I have grown old, so I ask her to take care of me because usually, daughters are better at taking care of her parents. If it was my son who lives with me, that would be my daughter in law who would take care of me, if she does so well and sincerely).

Nasruddin's quotes above make it clear about Maduresse parents' consideration in deciding the amount of property to each of heirs. The division is based on the highly valued concept of division of labor of men and women. It has been literally mentioned that a man should be responsible to earn money and fulfill what family needs, while a woman has no direct responsibility of it.

Another fact shows that in a rich Maduresse family, a new house would be built for a daughter and she would stay there as soon as she gets married. The house is usually built close to the parent's house or even made as pamolean, a place where all family members would go there in some special days or occasions and as the symbol to keep the family's wholeness. Relating to this, Anshori, a head of a household who stays in Kwanyar says that his daughter is chosen as

30 An interview at Nasruddin's house in August 3, 2018. 
pamolean because of the ewuh pakewuh consideration to other family members. He said that it would not be good if a son visits a pamolean's home and needs to ask for food from his sister in law (if another son becomes pamolean). ${ }^{31}$ Different from a daughter, a son usually gets a field as sangkolan.

Many kinds of Maduresse people's cultural construction about how the formation of traditional system of inheritance takes place becomes a shared value in transferring the wealth to the generation and is symbolized as Maduresse traditional legacy.

\section{The Istinbath of Female Inheritance using System Approach}

The compiled data shows that there founds some systemically interconnected elements in the practice of Madurese traditional legacy which then form the reality. Those elements live in the society's cultural system as the desired values of their life. Among others, it is mainly about the value of legacy division which pays attention mostly to the women. In understanding the construction and relation of each forming elements, it is considered proper to use the system approach of Jasser Audah. According to him, basic features of system approach are cognition, wholeness, openness, interrelated hierarchy, multidimensionality, and purposefulness. ${ }^{32}$

First of all, the application of this approach needs separation between the sacred content of religious texts (nash) and the cognitive "understanding" on it. This means that all law products of faqih coming from the reading of texts (nash) are ihtimal, meaning that it could contain either right or wrong. ${ }^{33}$ This very first step is called as cognition in system feature.

The Maduresse people's understanding on legacy practice seems dynamic. They generally think that legacy is not only a process when daughters/sons get inheritance (property) right from their parents, but also a process of entrusting good values that they need to keep it well as kak-cekkak (a kind of sacred trace) of parents to their kids. This very specific thing symbolizes the shifting perspective on

\footnotetext{
31 The interview with Ansori in October 7, 2018.

32 Jasser Auda, Maqãsid al-Sharĩ'ah as Philosophy of Islamic: A System Approach, 45-55

33 Abdul Wahab Khalẫf, Ilmu Ushũl Fiqh, (Lebanon:Dãr Kutub al-Islamiyah, 2010), 13
} 
inheritance from theological meaning to Maduresse societies' cultural values.

The shifting from theological into cultural realm makes the research object, Madurese traditional legacy, in Nur Syam's language, as the system of culture. ${ }^{34}$ Therefore, religion as a cultural system can be seen as pattern of behavior. In this case, religion is considered as the frame of interpretation on human's action or behavior, as famous as model for. While in another side, religion in society is also called as model of, where human's practical behavior creates a fact about religion itself. ${ }^{35}$ In a simpler explanation, it could be mentioned that people's behavior describes their understanding on religion. This understanding, in its turn, potentially gets unique inputs from the external elements which could be diverse among societies.

The changing perspective from dogmatic to human logical realm affects the Maduresse people's instinbath in deciding their legacy division and making it dynamic. The understanding of Qur'anic verse 2:1 is not only based on textual ones, but also on the local cultural setting so that it eventually affects the instinbath result. As the cultural concept of rampak naong, the responsibility to take care of the big family is given more to the daughter. In addition to it, the malo feeling which appears when there found a discord in a family also affects the legacy division. Those dreamed cultural values "force" Maduresse people to share and divide their wealth to the kids when the parents are still alive. This aims to avoid any family discord in Maduresse people's family system. The "forcing" power is local people's effort in understanding the Qur'anic verse 2:1 in the cultural language constructed in sangkolan legacy.

From the perspective of Islamic legacy concept, sangkolan heritance cannot be considered as legacy because the division happens when the giver is alive. ${ }^{36}$ Hence, based on Islamic epistemological law, this practice cannot be categorized as legacy, although people consider it as legacy. This kind of ijtihad is allowed

${ }^{34}$ Nur Syam, Islam Pesisir, (Yogyakarta:LkiS, 2005), 2

35 Clifford Geerzt, Kebudayaan dan Agama, translator, Fransisco Budiman Hardiman, (Yogyakarta : Kanisius, 1992,), 9

36 One of the requirements of legacy is the death of the giver. See Mustafã al-Khin, et.al, al-Figh al-Manhajĩ alã Madzhab al-Imãm al-Syafi'ĩ, Vol V, (Damaskus: Dãr Qalam, 1992), 74 
by figh as the application of grant (hibah) concept. Giving any grant (hibah) to the heirs is absolutely allowed. However, it is highly recommended to make fair division ${ }^{37}$ by not differentiating portion for men and women. 38

After the psychological side on the cognitive feature, the next element is the wholeness which, in this context, comes as the broad minded perspective on understanding reality. This wholeness feature is urgently needed as it is used to complete the ushul figh reading model that often gets trapped in atomistic and reductionistic approach. The automictic relies on one religious text (nash) without seeing another related nash to solve many kinds of religious problems in the society. This feature considers Al-Quran as a perfect related intact unity. Therefore, it is very compatible to use as the consideration in answering any law problem by observing the whole related texts and not only limited to law verses. ${ }^{39}$

In this specific context, this second feature can be used to see the fact of Maduresse traditional legacy and consider it as local people's whole understanding on their religion's nash. This is clear from the data about the equal amount division between the wealth given to the daughter and the son. Another datum even shows that daughter gets special treatment much more than the son. In fact, according to AlQuran concept, the sentence للذكر مثل حظ الأنثيين explains that the division for a son is two times much more than of a daughter. ${ }^{40}$

Those mentioned data eventually show that Maduresse people do not consider the legacy verse independently and solely as law theorem. In fact, they integrate it with the verse(s) of nafakah, particularly about the responsibility of earning money for family which belong to men instead of women. However, women are also supposed to help men in that role. The data above mention that other than those, a daughter is also supposed to care of her parents more

\footnotetext{
37 The justice concept in social life cannot be understood as the equality division. Justice is an ideal element in the law system. See, Bahder Jihan Nasution, "Kajian Filosofis tentang Hukum dan Keadilan (Dari Pemikiran Klasik sampai Pemikiran Modern)", in al-Ihkam, Vol 11, no. 2 Desember 2016, 273

${ }^{38}$ Mustafã al-Khin, et.al, al-Figh al-Manhajĩ ala Madzhab al-Imam al-Syafi'̃̃, Vol VI, (Damaskus: Dãr Qalam, 1992), 131-132.

39 Jasser Auda, Maqãsid al-Sharĩ'ah as Philosopy....., 46-47.
} 
than a how a son must do, although this obligation actually belongs to those two. A Maduresse woman also has a big role in keeping her family's unity as clear from its position as apamolean. All of those big and various roles of Maduresse women create a cultural wisdom to make gender equality in getting their legacy right.

From maqâshid syariah point of view, keeping the family's unity is one of Al-Quranr points that Moslem should maintain. Keeping the ukhuwah is the another main point of Islamic teaching, and the continuity of its maintenance is all Moslem's obligation. ${ }^{41}$ When the obligation of keeping the good relationship is combined with grant concept applied among Maduresse people, it is not contradictory to the spirit of Islamic law.

The next feature is openness or being open minded to every possibility of recovery and improvement. This feature is one of the characteristics of social sciences where the change is considered as something absolute. The changing of social aspect, cultural and many kinds of people's life aspects requires the law changing as the answer of any happening change. Based on the data, Maduresse traditional legacy practice has actually changed from hibbe (grant or voluntary giving) concept to sangkolan legacy concept. The changing of this legacy concept comes from strong religiosity of Maduresse people in one side and the strong solidarity to avoid any family discord or family's carok on the other side. However, this change does not affect on Maduresse people's perspective in considering the wealth as inheritance or sangkolan. The owenership of sangkolan is still considered valid among Maduresse both from the religious and cultural perspectives. ${ }^{4}$

That shifting of concept also aims as an effort to maintain the ideal family system or so called rampak naong. This kind of effort which is done consciously and well based on a concept, according to

\footnotetext{
41 See the discussion about maqâshid 'ammah in Thahir Ibnu 'Ãshur, Maqãshid alSyarĩ'ah al-Islamiyah, (Kairo: Dãr Kutub al-Misrĩ, 2011), 80-84.

42 The contradictory between the benefit connecting to the soul must be prioritized than those of connected to the goods. In this research context, the problem in the family unity and avoiding the mafsadat family controversy because of the unfair division must be maintained first than those of property division. 'Izzuddĩn Ibnu Abd Salãm, Mukhtashar al-Fawãid fĩ Ahkãm al-Maqãshid al-Ma'rũf bi al-Qawãid al-Sughrã, (Arab Saudi: Daar al-Furqan, 1997), 146.
} 
maqâshid syarîah through its system approach, is a practice of purposefulness feature. In other words, the purpose of the legacy understanding and its shift to the grant concept has no contradiction with the nash as explained above.

Based on the research data compiled, the values of Maduresse traditional legacy are the close relation of cultural, religious and social values that creates the unique traditional legacy practice. The values consist of the obedience on the religious teaching, family unity maintenance, and cultural preservation and economic improvement through the strong character and malo culture. The complicated relation model then creates a compromise legacy division that creates which fact could frame and represent the feature of interrelated hierarchy.

The last feature is multi dimensionality which involves many kinds of dimensions. Basically, this feature has two main concepts, rank and level. The rank concept in multidimension way of thinking explains the kinds of dimensions in a discussed object. Meanwhile, the level concept explains some levels that might be found in a dimension. Any normal thinking concept tends to find one dimension and two levels in a context. Therefore, it makes a contrary phenomenon because a fâqih only sees from a dimension and his conclusion should be different from the result of any normal thinking concept procedures. The practice of Maduresse traditional legacy can be seen through this multidimensional model as it makes not easy to contradict the existed legacy concepts. For example, the portion of a son should be two times higher than a daughter. According to this model, it is not contrary with the concept of fair among local people and the role of each child in the family. This specific point of view which consider all aspects ranging from social, culture and religion is appropriate to the Maduresse people's condition, mainly the position of women with more responsibility in maintaining the family's unity.

From all explanations above, it is crystal clear about Maduresse people's ijtihad on traditional legacy system they have applied for long. The effort of producing a compromise law product integrated with many life aspects for avoiding the contrary and fighting of each Moslem is religiously recommended. This is also the real practice of religion suggestions to be kind for each other through doing sulh in 
many matters especially the worldly matter ${ }^{43}$ to get the society's material benefits. 45

\section{Conclusion}

For Maduresse people, women have more responsibilities than men in maintaining the continuity and unity of the family. The women's task and position make their legacy be compromised with Maduresse cultural values so it can be fair with the men's part, even much more than what men could get. The law product of this compromise is formulated through unusual pattern of ijtihad using maqâshid syariah through its system features as the main analysis of Maduresse traditional legacy phenomenon.

\section{Bibliography}

Abd Salam, 'Izzuddin Ibnu, Mukhtashar al-Fawaid fi Ahkam al-Maqashid al-Ma'ruf bi al-Qawaid al-Sughra, Arab Saudi: Dar al-Furqan, 1997

Absori, "Transformation of Maqashid al-Syari'ah (an Overview of the Development of Islamic Law in Indonesia), in al-Ihkãm, vol 11, No I Juni 2016.

Auda, Jasser, Maqãshid al-Shari'ah as Philosophy of Islamic Law: a Sistems Approach, London: The International Institute of Islamic Thought, 2007

'Ashur, Thãhir Ibnu, Maqashid al-Syari'ah al-Islamiyah, Kairo: Dar Kutub al-Misri, 2011

'Âsyũr, Muhammad Thãhir Ibnu, Tafsĩr al-Tahrĩ wa al-Tanwiri, Tũnisia: al-Dãr al-Tũnisiyah li al-Nasr, s.a

al-Sayuti, al-Dzurr al-Manthür al-Tafsir bi al-Ma'tũr, Kairo: Markaz lil Buhũs wa al-Dirãsah al-'Arabiyyah wa al-Islamiyah, 2003

al-Yubi, Saad Ahmad, Maqãshid al-Syaríah al-Islamiyah wa Alãqatihã bi al-Adillah al-Syar'iyyah, Saudi Arabiya: Dãr Hijrah li an-Nasr wa al-Tawzi', 1993

al-Khin, Mustafã, dkk, al-Fiqh al-Manhajĩ alã Madzhab al-Imãm al-Syafíi, Vol V, Damaskus: Dãr Qalam, 1992

Danandjaja, James, Antropologi Psikologi: Teori, Metode, dan Sejarah Perkembangannya, Jakarta: Rajawali, 1988

\footnotetext{
43 Mustafã al-Khin, et.al, al-Figh al-Manhajĩ alã Madzhab al-Imam al-Syafíi, Vol. VI, (Damaskus: Dãr Qalam, 1992), 169
} 
Geerzt, Clifford, Kebudayaan dan Agama, transl: Fransisco Budiman Hardiman, Yogyakarta: Kanisius, 1992

Hanafi, Hasan, al-Ijtihäd al-Kalamĩ, Lebanon: Dar al-Hadi, 2002

Hallaq, Wael B., An Introduction to Islamic Law, (USA: Cambridge University Press, 2009

Khalaf, 'Abdul Wahãb, Ilmu Ushũl Fiqh, Jakarta: Dãr Kutub alIslamiyah, 2010

Maulana Surya Kusumah, “Sopan, Hormat, dan Islam Ciri-ciri Orang Madura", in Kepercayaan, Magi, dan Tradisi dalam masyarakat Madura, Jember: Penerbit Tapal Kuda, 2003

Maulidi, "Paradigma Progresif dan Maqashid Syariah: Manhaj Baru Menemukan Hukum Responsif", in Asy-Syir'ah: Jurnal Ilmu Syariah dan Hukum, Vol. 49 No. 2, Desember 2015

Mustafã al-Khin, dkk, al-Fiqh al-Manhaji alã Madzhab al-Imãm al-Syafíi'i, Vol VI, Damaskus: Dãr Qalam, 1992

Mutakin,Ali, "Teori Maqashid al-Syariah dan Hukubungannya Dengan Metode Istimbath Hukum" in Kanun Jurnal Ilmu Hukum, Vol. 19 No. 3, August 2017

Nasution, Bahder Jihan, "Kajian Filosofis tentang Keadilan Daba Hukum (Dari Pemikiran Klasik Hingga Modern)", in al-Ihkam, Vol. 11, No. 2 December 2016

Rahman, Fazlur, Islam, (London: Chicago University, 1979

Rifa'i, Mien, Manusia Madura, Jakarta: Pillar Media, 2007

Sadari, "Qur'anic Studies: Ber-ushul Fiqh dengan Maqashid Syariah sebagai Metode dalam Prespektif Adian Wahyudi, in Shahih, Vol 3 No. 1 January 2018.

Syam, Nur, Islam Pesisir, Jogjakarta: LkiS, 1995

Syafe'i, Rachmat, Ilmu Ushul Fiqih, Bandung: Pustaka Setia, 2015

Syuwaîh, 'Adil, Ta'lïl al-Ahkãm fĩ al-Syarí'ah al-Islamiyyah, Thanta: Dãr Basyĩr li al-Tsaqãfah wa al-`Ulũm, 2002

Thabrani, Abdul Mukti, "Maqashid Revitalization in Global Era: Istidlal Study from Text to Context" in al-Ihkam, Vol. 13 No.2 December 2018.

Tibi, Bassam, Islam and the Cultural Accomodation of Social Change, America: Wastview Press, 1991

Wiyata, Latief, Mencari Madura, Jakarta: Bidik-Phronesis Publishing, 2013 
The Study of Maqâshid Syarîa ah Toward Maduresse Traditional

Zuhayli, Wahbah al-., al-Tafsirr al-Munir: Fi al-'Aqĩdah wa al-Syarí'ah wa al-Manhaj, Damaskus: Dâr Fikr, 2003 